\title{
Impact of Manipulating Quail Eggs with Betaine During Early Embryogenesis on Chick Development, Hatchability, Hematological Variables, and Some Physiological Estimates
}

Ahmed Abdelkareem Abuoghaba ( $\sim$ abuoghaba@yahoo.com )

Sohag University Faculty of Agriculture

Fatma Ali

Aswan University

Amira Ahmed Mohamed Abdelwahab

Assiut University Faculty of Agriculture

Research Article

Keywords: Japanese quails, Betaine, Thermal stress, early embryogenesis, Reproduction

Posted Date: June 29th, 2021

DOI: https://doi.org/10.21203/rs.3.rs-634816/v1

License: @ (i) This work is licensed under a Creative Commons Attribution 4.0 International License. Read Full License 


\section{Abstract}

This study evaluated the effect of spraying incubated quail eggs with betaine on chick development, hatchability and some physiological estimates of Japanese quails during early embryogenesis. A total of 750 eggs were equally divided into two groups ( 2 groups $\times 5$ treatments $\times 5$ replicates $\times 15$ eggs). Eggs in the $1^{\text {st }}$ group were incubated at normal incubation temperature $\left(37.5^{\circ} \mathrm{C} / \mathrm{NIT}\right)$, while those in the $2^{\text {nd }}$ group were incubated at chronic incubation temperature $\left(39.5^{\circ} \mathrm{C} / \mathrm{CIT}\right)$ for 3 hours daily from the $4^{\text {th }}$ up to and $6^{\text {th }}$ day of incubation. Eggs in NIT and CIT groups were subjected to five treatments, T1 (negative control), T2 sprayed distilled water (positive control), while T3, T4, T5 groups sprayed distilled water supplemented with 500,1000 and $2000 \mathrm{mg}$ betaine/L respectively. The chick weight at hatch and slaughter weight and first egg weight was significantly impaired by CIT treatment. CIT group revealed a significant increase in the $\mathrm{H} / \mathrm{L}$ ratio and a significant decrease in T3 hormone and blood protein levels than the NIT group. Regarding betaine effects, the embryonic mortality rates, hatchability, hatched chick weight, and slaughter weight were significantly improved compared with the control. Also, betaine significantly increased blood protein and T3 hormone levels and significantly decrease the liver enzymes levels and total feed consumption compared with untreated group. The RV/TV ratio of quails in CIT group was significantly increased, while betaine treatment significantly decreased this ratio. Considering these results, it's strongly suggested that spraying of betaine on eggs at 1000 or $2000 \mathrm{mg} / / \mathrm{L}$ optimizes Japanese quails performance.

\section{Introduction}

Japanese quail (Coturnix coturnix japonica) farming offers potential alternatives for meat and eggs (Runjaić-Antić et al., 2010). Heat stress negatively affects poultry performance and causes economic losses (Niu et al., 2009; Mehaisen et al., 2017). The heat-stressed bird has low production performance due to a reduction of feed consumption (Abuoghaba et al., 2021). Also, heat stress adversely affects the physiology status of quails (Alagawany et al., 2017). In vertebrates, the environment of embryogenesis affects the development and health of individuals (Sandra et al., 2011). Indeed, incubation parameters including temperature affect the embryonic environment (Loyau et al., 2015). An inefficient heat impairs functionality of the physiological, immunological aspects and organs of quails which negatively influencing the hatchability (Abuoghaba et al., 2021). Therefore, several attempts to attenuate and alleviate the detrimental influences of heat stress on quails performance (Gholami et al., 2015; Mehaisen et al., 2017; Mehaisen et al., 2019).

Betaine is involved in many essential functions in cells allows water retention, thus aids in protecting cells from the dehydration effects and facilitates secretion of digestive enzymes (Eklund et al., 2006). Also, Betaine protects tissues include the leukocytes, kidney, liver, and brain (Klasing et al., 2002). The intracellular accumulation of betaine does not affect the cell component and functions (Gholami et al., 2015; Ratriyanto and Mosenthin 2018). Betaine is an important agent of the methionine (Met) cycle which is important for the regulation of genes (Anderson et al., 2012). Betaine supplementation has been widely utilized in the poultry industry for its osmoregulatory and methyl donor functions to maintain the intestinal health of birds especially reared under heat stress situations (Metzler-Zebeli et al., 2009). Moreover, dietary 
supplementation with betaine may protect digestive tract intestinal cells and microbes against osmotic variation (Ratriyanto et al., 2009). In Japanese quails, dietary betaine supplemented alone (Ratriyanto et al., 2018) and in combination with other dietary protein supplements (Ratriyanto et al., 2015) promotes the production. Studies have shown that betaine has beneficial properties in resistance to heat stress in poultry birds (Khan et al., 2012). The injection hatching eggs technique during incubation phase is considered a stressful procedure for embryos growing; in addition to, it requires experience and skill for application. Therefore, this study was planned to investigate the effect of spraying hatching eggs exposed to high incubation temperatures with betaine solutions during early incubation phase on chick development, hatchability, hematological variables and physiological status of Japanese quails.

\section{Materials And Methods}

The experiment was conducted at the Experimental Poultry Farm, Poultry Production Department, Faculty of Agriculture, Assiut University, Assiut, Egypt.

\section{Preparation of betaine solution}

Betaine solutions were freshly prepared by dissolving betaine powder in distilled water. Both betaine mixture solutions and distilled water were set in an incubator at $37.5^{\circ} \mathrm{C}$ for 2 hours before spraying.

\section{Egg incubation}

A total of 750 freshly fertilized Japanese quail eggs were collected from the flock reared under Assiut governorate atmosphere, at 20 weeks of age. All eggs were classified into two equal experimental groups ( 3 group $\times 5$ treatments $\times 5$ replicates $\times 15$ eggs). In the first group (control), eggs were incubated at $37.5^{\circ} \mathrm{C}$ and $55-60 \% \mathrm{RH}$ (normal incubation temperature/NIT) from day 0 up to 14 days of incubation. In the second group (chronic incubation temperature/CIT), eggs were daily exposed to $39.0^{\circ} \mathrm{C}$ and $55-60 \%$ for 3 successive days (E4-E6) during the early embryogenesis for 3 hours (14:00-17:00). Eggs in each group were classified into five spraying betaine treatments; in the $1^{\text {st }}$ one, eggs were not treated (negative control), while those in the $2^{\text {nd }}$ treatment were sprayed with distilled water only (Positive control). Eggs in the $3^{\text {rd }}, 4^{\text {th }}$ and $5^{\text {th }}$ treatments were sprayed with 500,1000 and $2000 \mathrm{mg}$ betaine per liter distilled water, respectively.

\section{Eggs treatments}

Egg surfaces were cleaned by using ethanol $100 \%$ before incubation. Eggs in the second group were transferred to the separate incubator and exposed to $39.0^{\circ} \mathrm{C}$ and $55 \%-60 \%$ relative humidity for three hours daily on days 4, 5 and 6 of incubation. All eggs were horizontally placed, and the solution was sprayed on the egg surface opposite to the air chamber. The eggshell was sprayed with $50 \mathrm{ml}$ betaine per 1000 eggs after heat exposure. All eggs were daily turned automatically 12 times i.e. every 2 hours (Aygun and Sert 2013).

\section{Studied variables}




\section{Egg weight loss (amount of moisture loss)}

The difference in the egg weight before setting in the incubator and on the $6^{\text {th }}$ day of incubation was used to determine the water loss amount and represented as the initial egg weight percentage.

\section{Embryonic mortality, hatchability traits of incubation and chick weight at hatch}

At the end of incubation period, the un-hatched eggs were broken to determine the embryonic mortality rate by using the equation: (number of dead embryos/whole viable egg numbers) $\times 100$, the chick cull rate was calculated as abnormal chick numbers/whole viable chick numbers at hatch) $\times 100$. At hatch, the hatchability rate was calculated as (hatch chick numbers/whole egg numbers) × 100 (Molenaar et al., 2011). The incubation time $(\mathrm{TEPH} / \mathrm{h})$ was calculated as the hour numbers from setting eggs in the incubator till hatch. All hatched chicks were weighed at hatch by using a digital balance, while relative chick weight $(\mathrm{RCW} / \%)$ were determined as (hatch chick weight / initial egg weight) $\times 100$. Ninety newlyhatched quails ( 2 groups $\times 5$ treatments $\times 3$ replicates $\times 3$ birds) were used to cloaca temperatures $\left({ }^{\circ} \mathrm{C}\right.$ ) temperatures by using a digital thermometer throughout inserting it one $\mathrm{cm}$ deep into the hatched-chick cloaca.

\section{Newly-hatched chick quality traits}

Approximately after 12 hours from the hatch, 100 dry chicks ( 2 groups $\times 5$ treatments $\times 5$ replicates $\times 2$ chicks) were randomly taken to determine chick weight and then killed by cervical dislocation to determine the residual yolk sac weight (YSW/g). After drying excessive quail embryonic fluids using absorbent papers, yolk sacs, heart, intestine, gizzard, liver and empty chick weight (ECW/\%) were weighed and represented as the chick weight at hatch percentage.

\section{Productive traits}

300 chicks ( 2 groups $\times 5$ treatments $\times 5$ replicates $\times 6$ chicks) from hatched chicks were individually weighed and placed in floor wooden pens from the first day of the growing period up to 15 days and then kept in the battery cages from 15 up to 42 days of age. From one day old till 14days, all chick quails were fed a ration containing 22.52\% CP and ME $12.78 \mathrm{MJ}$ kg-1, from days 15 to $28 \mathrm{~d}$ they were fed a diet containing 22.12\% CP and ME 14.14MJ kg-1 of diet, while from 28 to 42 day the chick was fed on a diet 21.0\% CP and ME 13.56 MJ kg-1 of diet. The feed and fresh tap water was offered ad-libitum all over the experimental period. The chick quails were daily exposed to 23 lighting hours (30-40 lux $\mathrm{m}^{2}$ ) during the experiment. All chicks were weekly weighed from hatch up to 42 days of age, while total weight gain (TWG) was measured according to the equation (The final body weight - initial body weight)/ number of days) during the experiment. Total feed consumption (TFC/g) was measured during the experiment, while feed conversion ratio (FCR) was calculated by dividing total feed consumption (TFC) by total weight gain ( $\mathrm{g}$ ) of chicks. Age at laying first egg (AFE/day) was calculated and the weight of first egg (WFE/g) was weighted and recorded.

\section{Slaughter traits}


At day 42 of the experiment, 100 female quails ( 2 groups $\times 5$ treatments $\times 5$ replicates $\times 2$ birds) were weighed and then slaughtered by cervical dislocation to measure eviscerated carcass (\%), heart parameters: (right ventricle (RV), total ventricle (TV) and RV/TV ratio, intestine (\%), liver (\%), gizzard (\%), spleen (\%), ovary (\%) and oviduct (\%) to life body weight. The largest ovarian follicles were weighed by using a digital balance.

\section{Hematological parameters, blood proteins, liver enzymes, cholesterol, T3 hormone}

At 42 days of age, 100 blood samples were collected from females (2 groups $\times 5$ treatments $\times 5$ replicates $\times 2$ birds) into heparinized tubes for hematological analysis. The plasma samples were taken after centrifugation the blood samples at $3000 \mathrm{rpm}$ for 15 minutes. Total protein $(\mathrm{mg} / \mathrm{dl})$, albumin $(\mathrm{mg} / \mathrm{dl})$ and globulin $(\mathrm{mg} / \mathrm{dl})$ were measured by using commercial kits according to (Trinder, 1969) and triiodothyronine (T3) hormone concentration determined by commercial kits. Hemoglobin $(\mathrm{Hb})$ concentration was spectrophotometrically measured; the numbers of red blood cell (RBCs $/ 10^{6}$ ) and white blood cells (WBC/103) were counted using a hemocytometer as described by (Schalm et al., 1975), while heterophils to lymphocyte (H/L) ratio were estimated as described by (Gross and Siegel 1983). Serum triglyceride, cholesterol, aspartate amino transferase (AST) and alanine amino transferase (ALT) were measured by using their accompanying commercial kits.

\section{Statistical analysis}

The data were subjected to statistically analysis by using to general linear model (GLM) of SAS (SAS Institute 2004) according to the model: $Y_{i j k}=\mu+I_{i}+B_{j}+I_{i j}+e_{i j k}$, Where $Y_{i j k}$ is an observation, $\mu$ is the overall mean, $I_{i}$ is the effect of incubation temperature $(i=1,2), B_{j}$ is the effect of the betaine dose $(j=1,2,3$, $4,5), I_{i j}$ is the effect of interaction between incubation temperature and betaine dose, and $e_{i j}$ is the random error. The differences between least squares means (LSM) were tested at $p<0.05$ level by using Duncan's multiple range test (Duncan, 1955).

\section{Results}

\section{Embryonic mortalities}

No significant differences were found among treatments for chick cull rate, egg weight, relative loss weight, and embryo quality traits (Table 1). No impact of the embryonic thermal manipulation was observed on the mortality rate. Regarding the effect of betaine treatments, the results revealed a significant decrease $(P=0.02 \& 0.03)$ in early and late embryonic mortalities. The interactions of incubation temperature and betaine treatments had no significant effect on these parameters.

\section{Hatchability traits, chick weight at hatch and cloaca temperature}

The data presented in Table 2 reveal no significant effects of incubation temperatures on hatchability percentages and relative chick weight. The high incubation temperature significantly $(p=0.023)$ decreased the incubation period, the TEPH as well as chick weight at hatch than the control group. Furthermore, the 
cloacal temperature in the NIT $\left(39.61^{\circ} \mathrm{C}\right)$ group was significantly $(p=0.002)$ lower than those reported in the CIT $\left(39.97^{\circ} \mathrm{C}\right)$ group.

Regarding betaine treatments, the results revealed a significant increase $(p=0.01)$ in the hatchability percentage and chick weight at hatch. No effect of the interaction between the betaine treatments and incubation temperature on these parameters.

\section{Carcass traits of newly-hatching chicks}

After hatch, the results revealed that chick weight before $(7.29 \mathrm{~g})$ and after the slaughter $(7.88 \mathrm{~g})$ in NIT group was significantly higher $(\mathrm{p}=0.01)$ than $(6.88$ and $7.34 \mathrm{~g})$ in CIT group (Tables 3$)$. Also, the heart percentage $(1.05 \%)$ was significantly lower $(p=0.01)$ in the CIT group than $(0.86 \%)$ in the NIT group. The liver percentage in the CIT group $(3.73 \%)$ was significantly higher $(p=0.002)$ than $(2.92 \%)$ in NIT group. The weights of chick before and after slaughtering were significantly higher $(p=0.04)$ in betaine-treated eggs (T4 and T5) than the control group. No effect of betaine treatment or interaction between incubation temperature and betaine treatment on the percentages of the intestine, liver and gizzard.

\section{Productive performance}

At 42 days after hatch, the results revealed that chick weight at 42 days of age $(212.2 \mathrm{~g})$ and the weight of the first egg $(7.59 \mathrm{~g})$ in CIT group was significantly higher $(\mathrm{p}=0.02)$ than $(217.5$ and $8.60 \mathrm{~g})$ in the NIT group (Tables 4). No effect of incubation temperatures on the total weight gain, total feed consumption, feed conversion ratio and age at laying first egg.

The betaine treatments significantly $(p=0.04 \& 0.002)$ increase the chick weight at $42 d$, total weight gain and the weight of first egg. Also, the total feed consumption and feed conversion ratio were significantly $(p=0.0001)$ decreased compared with control group. No impact of the interaction between incubation temperature and betaine treatment on these parameters except for total feed consumption and feed conversion rate were significantly decreased.

\section{Carcass traits of female quails}

At 42 days of age, the results presented in Tables 5 revealed that RV and RV/TV ratio in the CIT group were $(0.493$ and $0.308 \mathrm{~g})$ significantly higher $(p \leq 0.05)$ than $(0.418$ and $0.205 \mathrm{~g})$ in the NIT group. While, spleen percentage $(0.049 \%)$ significantly $(p=0.02)$ decreased than $(0.065 \%)$ in the NIT group. The RV/TV ratio in quails treated with betaine significantly $(p=0.001)$ decreased than those of the control group. No significant effect due to interaction between incubation temperature and betaine treatment on these parameters.

\section{Effects of incubation temperature and betaine treatment on female reproductive traits}

Data presented in Table 6 showed no significant effect of the incubation temperatures on the percentages of ovary and oviduct as well as follicle weights. Regarding betaine treatments $(T 4, T 5)$ significantly $(p=0.013)$ increased oviduct percentage compared with other groups. No effect of the interaction between incubation temperature and betaine treatment on female reproductive traits. 


\section{Hematological parameters and blood proteins of female quails}

From data in Table 7, the RBCs $\left(\times 10^{6}\right)$ and $\mathrm{H} / \mathrm{L}$ ratio in the CIT group were significantly $(\mathrm{p}=0.01$ \& $p=0.0001)$ increased, while WBC $\left(\times 10^{3}\right)$, total protein, albumin and globulin were significantly $(p=0.001)$ decreased than in the NIT group. $\mathrm{Hb}(\mathrm{g} \mathrm{dL}-1)$ was not affected. Regarding the effect of betaine treatments the WBC $\left(\times 10^{3}\right)$, total protein, albumin and globulin were significantly $(p=0.001)$ increased than those of the control groups. No effect due to interaction between incubation temperature and betaine treatment on all parameters.

\section{Liver enzyme triglyceride, cholesterol and T3 hormone of female quails}

From data in Table 8, the ALT, AST, triglyceride and cholesterol in the CIT group were significantly $(p=0.001)$ increased, while T3 hormone $(\mu \mathrm{L}-1)$ significantly $(p=0.001)$ decreased than in the NIT group. Regarding the effect of betaine, the ALT, AST, triglyceride and cholesterol in the treated groups were significantly $(p \leq 0.05)$ decreased, while T3 hormone significantly $(p=0.027)$ increased than those of the control group. No effect of the interaction between incubation temperature and betaine treatment on the liver enzymes, triglyceride, cholesterol and T3 hormone of female quails.

\section{Discussion}

In the present study, Incubation temperature manipulation during embryogenesis had negative long-lasting effects on quail development and physiology, including weight and production performance traits. The results revealed incubation period and TEPH were significantly decreased by thermal stress similar to previous findings in quails (Piestun et al., 2008; Alkan et al., 2013; Sgavioli et al., 2015). The chicks cloacal temperature in the CIT group was significantly $(\mathrm{p} \leq 0.05)$ increased compared with control as indicated by (Abuoghaba, 2017) suggesting that heat stress caused internal temperature dysregulation. The achieved results showed no impact of thermal manipulation during quail's embryogenesis in embryonic mortality and hatchability percentages similar results were obtained in previous studies in quails (Alkan et al., 2013; Vitorino Carvalho et al., 2020).

Previous studies in broilers revealed heat stress impact on weights of newly hatched chicks as well as weights before and after slaughtering (Abuoghaba, 2017). Similarly in quails, the results showed a negative impact of thermal stress on newly hatched quail weights. The heart weight was significantly lower in CIT group than in the control group. Also, in broilers the heart weight was decreased in the heat-stressed group may be related to the increased susceptibility of cardiovascular disorders such as ascites (Leksrisompong et al., 2007, Abuoghaba, 2017). The liver weight was significantly higher ( $p \leq 0.05)$ in CIT group than in the control group. These findings agree with (Sgavioli et al., 2015) who found that incubation heat stress led to an increase in liver weight as well as a decrease in heart weight in broilers. At slaughter age (D42) in female quails, the quail's weight and weight of the first egg were significantly decreased by incubation thermal manipulation this may be due to decrees in the initial body weight of the chick that affected the final body weight. These results agreed with the findings of (Hulet et al., 2007). 
The slaughter weights of TV (g), and spleen (\%) were significantly decreased, while RV and RV/TV ratio were significantly increased by incubation thermal manipulation. These results are in agreement with findings in broilers (Molenaar et al., 2011). The increase in RV/TV ratio was an indicator for ascites (Wideman, 2001). No impacts of thermal stress were observed in the female reproductive traits.

The obtained findings showed adverse impacts of thermal stress on quail blood parameters. The CIT quails displayed a higher number of red blood cells and $\mathrm{H} / \mathrm{L}$ ratio than the control group similar results were obtained in quails (Mehaisen et al., 2019) and in broilers (Abuoghaba, 2017). The increase of the H/L ratio is an indicator of stress in quails (Nazar and Marin, 2011). Furthermore, the total leucocyte count reduction in CIT quails may be due to increased corticosterone levels which increased in response to heat stress (Mehaisen et al., 2017; Mehaisen et al., 2019).

The total protein, albumin, and globulin levels in the CIT groups were significantly decreased compared with the control group as previously seen in quails (Mehaisen et al., 2019). These results could be explained by heat stress-induced increase levels of CORT which included denaturation and breakdown of protein (Sahin et al., 2006; Mehaisen et al., 2019).

The thermal stress resulted in a decrease T3 level which was observed in CIT females compared with NIT females as previously seen in quails (Badran et al., 2012) and broiler (Yalçın et al., 2009; Abuoghaba, 2017). The increase in ALT and AST enzymes is an indicator of the harmful effects of heat stress in liver tissues (Vahdatpour et al., 2011). These results are consistent with the obtained findings that ALT and AST enzymes were significantly increased in CIT quails compared to NIT quails. Furthermore, lipase enzyme activity becomes low at heat stress with low digestion of nutrients (Al-Zghoul et al., 2019). Therefore, CIT quails were displayed higher concentrations of triglyceride and cholesterol compared to NIT quails. This is in agreement with a previous study in quails (Sahin et al., 2006).

Positive impacts of nutrients in ovo administration including support egg nutrients (Foye et al., 2006) increase chick weight at hatch day (Saki et al., 2014) and improve the immune system (Sławinska et al., 2014). The embryonic mortality in the betaine-treated eggs decreased compared with those of the control group. Spraying of betaine improved hatchability percent compared with a control group. Furthermore, increasing betaine level caused a numerical increase in hatchability percent. These results agree with the report of (Gholami et al., 2015) that increasing in ovo injected betaine level improved hatchability percent. Hatch weight was significantly affected by betaine treatments. These results agree with those of (Saki et al., 2014; Gholami et al., 2015) that the betaine administration improved hatching weight. Interestingly, the interaction between incubation temperature and betaine treatment significantly decreases the relative water loss may be due to betaine is an osmoregulatory agent that increases water retention (Attia et al., 2005), and reduce water evaporation from the eggs or may be due to the ability of betaine to substitute methyl group donor such as Met (Metzler-Zebeli et al., 2009).

Newly hatched chick weights before and after slaughter were significantly increased with betaine spraying (T4 and T5). No impacts of betaine spraying in internal organ weights were observed. 
At slaughter age, BW and TWG were significantly affected by experimental treatments, spraying of betaine improved BW and TWG than control groups. The obtained results agree with (Gholami et al., 2015) that betaine administration improved the final weight of chickens. These positive effects of betaine could be attributed to betaine can replace methyl group donors such as Met (Metzler-Zebeli et al., 2009) therefore decreased Met needed (McDevitt et al., 2000). In ovo administration of Met would increase utilization of amino acids, deposition of protein, and improve BW in geese (Li et al., 2015).

Positive impacts were obtained by spraying different betaine levels in incubated eggs. Total feed consumption and feed conversion ratio were significantly decreased by betaine spraying. Due to its osmotic properties, betaine may have the potential to improve the digestibility of nutrients, improved protein utilization, and reduced protein breakdown (Eklund et al., 2006). In laying hens, the betaine supplementation in the diets increased FC (Ezzat et al., 2011). Previous reports have revealed that betaine supplementation improves nutrient digestibility because of its osmoprotective properties and supporting intestinal microbes growth (Ratriyanto et al., 2009; Ratriyanto et al., 2010). Furthermore, betaine significantly decreased the total feed consumption and feed conversion ratio in quails under heat stress. Similar findings in the broiler, that dietary betaine supplementation increased the feed intake and reduced the FCR of broilers subjected to heat stress (Attia et al., 2009; Sakomura et al., 2013; Chand et al., 2017).

The betaine spraying in the eggs would improve the feed intake, feed conversion, and body weight gain in post-hatch life this was confirmed by starting egg-laying at earlier ages and improve the weight of the first egg (Table 4).

This in agreement with previous observations in laying hens indicated that betaine supplementation in the diets increased egg weight (Ezzat et al., 2018), who found that the feed conversion ratio, egg production and egg mass in Mamourah chickens fed the diet containing $1600 \mathrm{mg}$ betaine $+600 \mathrm{mg} / \mathrm{Kg}$ GAA under summer conditions in Egyptian significantly $(P<0.01)$ improved in hens as compared to the control group.

The observed increase in the egg weight may due to higher egg components with betaine supplementation. These results may be attributed to the methyl donor function of betaine, which is involved in protein and energy metabolism (Ratriyanto et al., 2009). Supplementation of betaine improved and increased egg albumen weight (Joseph et al., 2000). Also, the oviduct \% was increased due to spraying betaine in incubated eggs these findings agree with the effects of dietary supplementation of betaine in laying hen (Attia et al., 2011).

In this study, when spraying betaine in heat-stressed eggs, the carcass traits were subsequently improved. Interaction between betaine and incubation heat stress significantly increases the EC weight and normalizes the spleen weight. Moreover, betaine treatments and the interaction between betaine and incubation temperature significantly decrease the RV/TV ratio. Consistent with the obtained results in broiler, dietary betaine supplementation enhances and improves the carcass traits of heat-stressed chicks (Attia et al., 2009; Rao et al., 2011; Nofal et al., 2015).

No impact of betaine in blood parameters except total leukocyte count significantly increased this in line with that betaine improve the immune status of the birds through protecting leukocytes (Klasing et al., 
2002).

Serum ALT and AST are important indexes of liver status. ALT and AST were decreased by spraying betaine to incubated eggs this may be due to betaine protects the liver (Klasing et al., 2002). Betaine increases the choline availability for the synthesis of very low-density lipoprotein, which avoids deposition of fat in the liver and increases the removal of fat from the liver (Attia et al., 2005; Ratriyanto and Mosenthin 2018).

Betaine treatment decreased serum lipids, triglyceride, and cholesterol. This was in agreement with the findings in quails (El-Bahr et al., 2021) and in laying hens (He et al., 2015), that betaine supplementation increased lipase activity and reduced the concentration of triglyceride and cholesterol (Ratriyanto et al., 2009).

Betaine treatment elevated serum levels of T3 hormone. The activity of T3 hormone is positively impacted with betaine compared to the control group. Accordingly, it's reported that betaine supplementation elevated the thyroid activity in broilers as indicated by increases in the levels of T3 hormone (Nofal et al., 2015; Attia et al., 2011). Besides, the obtained results revealed that betaine supplementation increased levels of total protein and globulin as previously reported in laying hens (Rao et al., 2011).

In conclusion, the spraying betaine in eggs during incubation phase would likely reduce the mortality rate, feed intake and feed conversion as well as improve hatchability rate, chick weight at hatch, chick weight at slaughter age, so that quail birds start the egg-laying at earlier ages. This could be reflected positively on the egg weight and egg quality traits. Moreover, betaine positively improves the WBC, blood proteins, liver enzymes, blood lipids, and thyroid activity. Under heat stress conditions the results showed increase cloacal temperature, RV/TV ratio, H/L ratio, ALT, AST, cholesterol, triglyceride levels in quail. While, the hatching time, chick weight at hatch, chick weight at slaughter age, the weight of the first egg, TWBC's and blood proteins were significantly decreased compared to the control group.

The present data showed that spraying of betaine could reduce the adverse effects of heat stress on RWL, TFC, FCR, carcass weight and RV/TV ratio indicating that betaine has an anti-heat stress role. The beneficial impacts of betaine on quail's performance may be due to its osmoregulatory action, methyl group donors and anti-oxidative effect.

\section{Declarations}

\section{Author contribution}

Conceptualization: A. A. Abuoghaba and Amira. A. M. Abdelwahab; methodology: A. A. Abuoghaba and Amira. A. M. Abdelwahab; statistical analysis: A. A. Abuoghaba; data collection: A. A. Abuoghaba, and Amira. A. M. Abdelwahab; writing (original draft preparation): A. A. Abuoghaba, Fatma Ali and Amira. A. M. Abdelwahab; writing (review and editing): A. A. Abuoghaba, Fatma Ali and Amira. A. M. Abdelwahab; supervision: A. A. Abuoghaba, Fatma Ali and Amira. A. M. Abdelwahab 
Funding This work was not financially supported by the Assiut University, but was self-financed at our own expense.

Data availability Data will be made available on reasonable request.

Code availability Data were analyzed using SAS (9.1).

Ethics approval All the procedures used in this study have been approved by the Institutional Animal Ethics Committee (IAEC) of Assiut University, Egypt.

\section{Conflict of interest}

The authors declare that no conflict of interest.

\section{Acknowledgments}

This study was performed at Experimental Poultry Farm, Poultry production Department, Faculty of Agriculture, Assiut University, Assiut, Egypt.

\section{References}

1. Abuoghaba, A.A., 2017. Impact of spraying incubated eggs submitted to high temperature with ascorbic acid on embryonic development, hatchability, and some physiological responses of hatched chicks. Can. J. Anim. Sci. 97, 172-182.

2. Abuoghaba, A.A., Ali, F., Ismail, I.I., Saleh, M., 2021. Impact of acute short term high thermal stress during early embryogenesis on hatchability, physiological body reaction and ovarian follicles development of quails. Poult. Sci. 100, 1213-1220.

3. Al-Zghoul, M.B., Saleh, K.M.M., Jaradat, Z.W., 2019. Expression of digestive enzyme and intestinal transporter genes during chronic heat stress in the thermally manipulated broiler chicken. Poult. Sci. 98, 4113-4122.

4. Alagawany, M., Farag, M., Abd El-Hack, M., Patra, A., 2017. Heat stress: effects on productive and reproductive performance of quail. World's Poult. Sci. J. 73, 747-756.

5. Alkan, S., Karsli, T., Karabag, K., Galic, A., Balcioglu, M.S., 2013. The effects of thermal manipulation during early and late embryogenesis on hatchability, hatching weight and body weight in Japanese quails (Coturnix coturnix japonica). Arch. Anim. Breed. 56, 789-796.

6. Anderson, O. S., Sant, K.E., Dolinoy, D.C., 2012. Nutrition and epigenetics: an interplay of dietary methyl donors, one-carbon metabolism and DNA methylation. J. Nutri. Biochem. 23, 853-859.

7. Attia, Y., Hassan, R., Shehatta, M., Abd-El-Hady, S.B., 2005. Growth, carcass quality and serum constituents of slow growing chicks as affected by betaine addition to diets containing 2 . Different levels of methionine. Int. J. Poult. Sci. 4, 856-865.

8. Attia, Y., Hassan, R., Qota, E., 2009. Recovery from adverse effects of heat stress on slow-growing chicks in the tropics 1: Effect of ascorbic acid and different levels of betaine. Trop. Anim. Health and 
Prod. 41, 807-818.

9. Attia, Y., Ahmed, A., Mervat, A., Abdelhamid, E., Bahaa, M., 2011. Effect of betaine with or without two antioxidiant on the performance of dual purpose breeding hens exposed to heat stress. J. Agric. And Env. Sci. Dam. Univ. Egypt. 10, 2011.

10. Aygun, A., Sert, D., 2013. Effects of prestorage application of propolis and storage time on eggshell microbial activity, hatchability, and chick performance in Japanese quail (Coturnix coturnix japonica) eggs. Poult. Sci. 92, 3330.

11. Badran, A.M., Desoky, A., Abou-Eita, E.M., Stino, F., 2012. Epigenetic thermal adaptation of chickens during late embryonic development. Egy. Poult. Sci. 3, 675-689.

12. Chand, N., Naz, S., Maris, H., Khan, R.U., Khan, S., Qureshi, M.S., 2017. Effect of betaine supplementation on the performance and immune response of heat stressed broilers. Pak. J. Zool. 49.

13. Duncan, D.B., 1955. Multiple range and multiple F tests. Biomet. 11, 1-42.

14. Eklund, M., Mosenthin, R., Tafaj, M., Wamatu, J., 2006. Effects of betaine and condensed molasses solubles on nitrogen balance and nutrient digestibility in piglets fed diets deficient in methionine and low in compatible osmolytes. Arch. Anim. Nutri. 60, 289-300.

15. El-Bahr, S.M., Shousha, S., Khattab, W., Shehab, A., El-Garhy, O., El-Garhy, H., Mohamed, S., Ahmed-Farid, O., Hamad, A., Sabike, I., 2021. Impact of Dietary Betaine and Metabolizable Energy Levels on Profiles of Proteins and Lipids, Bioenergetics, Peroxidation and Quality of Meat in Japanese Quail. Animals.11, 117.

16. Ezzat, W., Shoeib, M., Mousa, S., Bealish, A., Ibrahiem, Z., 2011. Impact of betaine, vitamin C and folic acid supplementations to the diet on productive and reproductive performance of Matrouh poultry strain under Egyptian summer condition. Egy. Poult. Sci. J. 31, 521-537.

17. Ezzat, W., Habeib, A.A., Rizk, Y.S., Beshara, M.M., 2018. Effects of betaine with different levels of Guandino acetic acid supplementation on productive and reproductive performance of local Mamourah strain during summer season in Egypt. J. Product. \& Dev., 23, 691-715.

18. Foye, O., Uni, Z., Ferket, P., 2006. Effect of in ovo feeding egg white protein, $\beta$-hydroxy- $\beta$-methylbutyrate, and carbohydrates on glycogen status and neonatal growth of turkeys. Poult. Sci. 85, 1185-1192.

19. Gholami, J., Qotbi, A.A., Seidavi, A., Meluzzi, A., Tavaniello, S., Maiorano, G., 2015. Effects of in ovo administration of betaine and choline on hatchability results, growth and carcass characteristics and immune response of broiler chickens. Italian J. Anim. Sci. 14, 3694.

20. Gross, W.B.M., Siegel, H.S., 1983. Evaluation of the heterophil/lymphocyte ratio as a measure of stress in chickens. Avian Dis. 27, 972-979.

21. He, S., Zhao, S., Dai, S., Liu, D., Bokhari, S.G., 2015. Effects of dietary betaine on growth performance, fat deposition and serum lipids in broilers subjected to chronic heat stress. Anim. Sci. J. 86, 897-903.

22. Hulet, R., Gladys, G., Hill, D., Meijerhof, R., El-Shiekh, T., 2007. Influence of egg shell embryonic incubation temperature and broiler breeder flock age on posthatch growth performance and carcass characteristics. Poult. Sci. 86, 408-412. 
23. Joseph, N., Robinson, F., Korver, D., Renema, R., 2000. Effect of dietary protein intake during the pulletto-breeder transition period on early egg weight and production in broiler breeders. Poult. Sci. 79, 17901796.

24. Khan, R., Naz, S., Nikousefat, Z., Selvaggi, M., Laudadio, V., Tufarelli, V., 2012. Effect of ascorbic acid in heat-stressed poultry." World's Poult. Sci. J. 68, 477-490.

25. Klasing, K., Adler, K., Remus, J., Calvert, C., 2002. Dietary betaine increases intraepithelial lymphocytes in the duodenum of coccidia-infected chicks and increases functional properties of phagocytes. $\mathrm{J}$. nutr.132, 2274-2282.

26. Leksrisompong, N., Romero-Sanchez, H., Plumstead P.W., Brannan, K.E., Brake, J., 2007. "Broiler incubation. 1. Effect of elevated temperature during late incubation on body weight and organs of chicks. Poult. Sci. 86, 2685-2691.

27. Li, D., Xu, H., Teng, Z., Zhou, H., Gao, G., Lou, Y., 2015. Effect of in ovo injection of methionine on growth performance and serum profile in landaise geese. Chin. J. Anim. Sci. 19, $43-48$.

28. Loyau, T., Bedrani, L., Berri, C., Métayer-Coustard, S., Praud, C., Coustham, V., Mignon-Grasteau, S., Duclos, M.J., Tesseraud, S., Rideau, N., 2015. Cyclic variations in incubation conditions induce adaptive responses to later heat exposure in chickens: a review. Animal. 9, 76-85.

29. McDevitt, R., Mack, S., Wallis, I. 2000. Can betaine partially replace or enhance the effect of methionine by improving broiler growth and carcase characteristics? British Poult. Sci. 41, 473-480.

30. Mehaisen, G.M., Ibrahim R.M., Desoky, A.A., Safaa, H.M., El-Sayed, O.A., Abass, A. O., 2017. The importance of propolis in alleviating the negative physiological effects of heat stress in quail chicks. Plos one 12, e0186907.

31. Mehaisen, G.M., Desoky, A.A., Sakr, O.G., Sallam, W., Abass, A.O., 2019. Propolis alleviates the negative effects of heat stress on egg production, egg quality, physiological and immunological aspects of laying Japanese quail. Plos one. 14: e0214839.

32. Metzler-Zebeli, B., Eklund, M., Mosenthin, R., 2009. Impact of osmoregulatory and methyl donor functions of betaine on intestinal health and performance in poultry. World's Poult. Sci. J. 65, 419-442.

33. Molenaar, R., Hulet R., Meijerhof R., Maatjens C., Kemp B., Van Den Brand H., 2011. High eggshell temperatures during incubation decrease growth performance and increase the incidence of ascites in broiler chickens. Poult. Sci. 90, 624-632.

34. Nazar, F., Marin, R., 2011. Chronic stress and environmental enrichment as opposite factors affecting the immune response in Japanese quail (Coturnix coturnix japonica). Stress. 14, 166-173.

35. Niu, Z., Liu, F., Yan, Q., Li, W., 2009. Effects of different levels of vitamin E on growth performance and immune responses of broilers under heat stress. Poult. Sci. 88: 2101-2107.

36. Nofal, M., Magda, A.G., Mousa, S., Doaa, M., Bealsh A., 2015. Effect of dietary betaine supplementation on productive, physiological and immunological performance and carcass characteristic of growing developed chicks uinder the condition of heat stress.Egy. Poult. Sci. J. 35: 237-259.

37. Piestun, Y., Shinder, D., Ruzal, M., Halevy, O., Yahav, S., 2008. The effect of thermal manipulations during the development of the thyroid and adrenal axes on in-hatch and post-hatch thermoregulation. 
J. Therm. Biol. 33: 413-418.

38. Rao, S., Raju, M., Panda, A., Saharia, P., Sunder, G.S., 2011. Effect of supplementing betaine on performance, carcass traits and immune responses in broiler chicken fed diets containing different concentrations of methionine." Asian-Australasian J. Anim. Sci. 24: 662-669.

39. Ratriyanto, A., Indreswari, R., Nuhriawangsa, A.M., Haryanti, A.E., 2015. Performance of japanese quails fed different protein levels and Supplemented with betaine. International Seminar on Tropical Animal Production (ISTAP).

40. Ratriyanto, A., Indreswari, R., Dewanti, R., Wahyuningsih, S., 2018. Egg quality of quails fed low methionine diet supplemented with betaine. IOP Conference Series: Earth and Environmental Science, IOP Publishing.

41. Ratriyanto, A., Mosenthin, R., 2018. Osmoregulatory function of betaine in alleviating heat stress in poultry. J. Anim. Physiol. Anim. Nutri. 102: 1634-1650.

42. Ratriyanto, A., Mosenthin, R., Bauer, E., Eklund, M., 2009. Metabolic, osmoregulatory and nutritional functions of betaine in monogastric animals. Asian-Australasian J. Anim. Sci. 22: 1461-1476.

43. Ratriyanto, A., Mosenthin, R., Jezierny, D., Eklund, M., 2010. Effect of graded levels of dietary betaine on ileal and total tract nutrient digestibilities and intestinal bacterial metabolites in piglets. J. Anim. Physiol. Anim. Nutri. 94: 788-796.

44. Runjaić-Antić, D., Pavkov, S., Lević, J., 2010. Herbs in a sustainable animal nutrition." Biotech. Anim. Husband. 26: 203-214.

45. Sahin, K., Onderci, M., Sahin, N., Gursu, M.F., Khachik., Kucuk, O., 2006. Effects of lycopene supplementation on antioxidant status, oxidative stress, performance and carcass characteristics in heat-stressed Japanese quail. J. Therm. Biol. 31: 307-312.

46. Saki, A., Abbasinezhad, M., Rafati A., 2014. Iron nanoparticles and methionine hydroxy analogue chelate in ovo feeding of broiler chickens. Inter. J. Nanosci. Nanotech. 10: 187-196.

47. Sakomura, N., Barbosa, N., Longo, F., Da Silva, E., Bonato, M., Fernandes, J., 2013. Effect of dietary betaine supplementation on the performance, carcass yield, and intestinal morphometrics of broilers submitted to heat stress. Braz. J. Poult. Sci. 15: 105-112.

48. Sandra, O., Mansouri-Attia, N., Lea, R.G., 2011. Novel aspects of endometrial function: a biological sensor of embryo quality and driver of pregnancy success."Reprod. Fertli. and Develop. 24: 68-79.

49. SAS., 2004. Statistical Analysis Systems Institute. SAS/STAT User's Guide: Release 6.03. SAS institute Inc., Cary, NC.

50. Schalm, O., Jain, N., Carroll, E., 1975. Veterinary Haematology, Lea and Febiger. Philedelphia, USA 807.

51. Sgavioli, S., Matos Júnior, J., Borges, L., Praes, M., Morita, V., Zanirato, G., Garcia, R., Boleli, I., 2015. Effects of ascorbic acid injection in incubated eggs submitted to heat stress on incubation parameters and chick quality. Braz. J. Poult. Sci. 17: 181-189.

52. Sławinska, A., Siwek, M.Z., Bednarczyk, M. F., 2014. Effects of synbiotics injected in ovo on regulation of immune-related gene expression in adult chickens. American J. Vet. Res. 75: 997-1003. 
53. Trinder, P., 1969. Determination of blood glucose using an oxidase-peroxidase system with a noncarcinogenic chromogen. J. Clin. Pathol. 22: 158-161.

54. Vahdatpour, T., Nikpiran, H., Babazadeh, D., Vahdatpour, S., Jafargholipour, M.A., 2011. Effects of Protexin $\circledast$, Fermacto ${ }^{\circledR}$ and combination of them on blood enzymes and performance of Japanese quails (Coturnix Japonica). Ann. Biol. Res. 2: 283-291.

55. Vitorino Carvalho, A., Hennequet-Antier, C., Crochet, S., Bordeau, T., Couroussé, N., Cailleau-Audouin, E., Chartrin, P., Darras, V.M., Zerjal, T., Collin A., 2020. Embryonic thermal manipulation has short and longterm effects on the development and the physiology of the Japanese quail. PloS one 15: e0227700.

56. Wideman, R., 2001. Pathophysiology of heart/lung disorders: pulmonary hypertension syndrome in broiler chickens." World's Poult. Sci. J. 57: 289-307.

57. Yalçın, S., Bruggeman, V., Buyse, J., Decuypere, E., Cabuk, M., Siegel, P., 2009. "Acclimation to heat during incubation: 4 . Blood hormones and metabolites in broilers exposed to daily high temperatures. Poult. Sci. 88: 2006-2013.

\section{Tables}

Table1 Impact of incubation temperature, betaine manipulations and their interaction on relative water loss of incubated eggs at 6 days of age and embryonic mortality rates 


\begin{tabular}{|c|c|c|c|c|c|c|c|c|}
\hline \multirow[t]{2}{*}{ Traits } & \multirow{2}{*}{$\begin{array}{l}\text { IEW } \\
\text { (g) }\end{array}$} & \multirow{2}{*}{$\begin{array}{l}\text { EW } \\
(g- \\
6 d)\end{array}$} & \multirow{2}{*}{$\begin{array}{c}\text { RWL } \\
(\%)\end{array}$} & \multicolumn{4}{|c|}{ Embryonic mortality rate (\%) } & \multirow{2}{*}{$\begin{array}{l}\text { Chick cull } \\
\text { rate (\%) }\end{array}$} \\
\hline & & & & $\begin{array}{l}\text { Early (0- } \\
7 d)\end{array}$ & $\begin{array}{l}\text { Late } \\
(8- \\
17 d)\end{array}$ & $\begin{array}{l}\text { Before } \\
\text { piping } \\
(\%)\end{array}$ & $\begin{array}{l}\text { After } \\
\text { piping } \\
(\%)\end{array}$ & \\
\hline \multicolumn{9}{|c|}{ Incubation temperature (IT) } \\
\hline $\operatorname{NIT}\left(37.5^{\circ} \mathrm{C}\right)$ & 11.03 & 10.16 & 7.93 & 10.67 & 9.47 & 5.67 & 3.07 & 2.33 \\
\hline $\operatorname{CIT}\left(39.0^{\circ} \mathrm{C}\right)$ & 11.05 & 10.07 & 8.92 & 9.07 & 8.27 & 6.13 & 2.53 & 2.00 \\
\hline SEM & 0.10 & 0.10 & 0.35 & 1.26 & 0.75 & 0.55 & 0.74 & 0.63 \\
\hline \multicolumn{9}{|c|}{ Betaine manipulations (BM) } \\
\hline $\begin{array}{l}\text { T1(Negative } \\
\text { control) }\end{array}$ & 11.05 & 10.08 & 8.89 & $12.67^{\mathrm{a}}$ & $12.67^{\mathrm{a}}$ & 6.00 & 4.00 & 1.33 \\
\hline $\begin{array}{l}\text { T2(Positive } \\
\text { control) }\end{array}$ & 10.96 & 10.01 & 8.70 & $11.67^{\mathrm{a}}$ & $8.67^{b}$ & 5.33 & 2.50 & 3.17 \\
\hline T3(500mg/L) & 11.16 & 10.23 & 8.45 & $10.00^{\mathrm{ab}}$ & $7.67^{b}$ & 6.67 & 3.17 & 1.83 \\
\hline $\mathrm{T} 4(1000 \mathrm{mg} / \mathrm{L})$ & 11.14 & 10.27 & 7.78 & $7.83^{b}$ & $7.67^{b}$ & 6.00 & 2.83 & 2.00 \\
\hline T5(2000mg/L) & 10.91 & 10.01 & 8.32 & $7.17^{b}$ & $7.67^{b}$ & 5.50 & 1.50 & 2.50 \\
\hline SEM & 0.15 & 0.15 & 0.56 & 2.00 & 1.19 & 0.87 & 1.17 & 0.99 \\
\hline \multicolumn{9}{|l|}{ Probability } \\
\hline IT & 0.884 & 0.505 & 0.056 & 0.382 & 0.273 & 0.555 & 0.617 & 0.712 \\
\hline BM & 0.732 & 0.628 & 0.685 & 0.027 & 0.031 & 0.834 & 0.661 & 0.742 \\
\hline IT×BM & 0.553 & 0.318 & 0.209 & 0.989 & 0.994 & 0.928 & 0.887 & 0.929 \\
\hline
\end{tabular}

A, b Means with different superscripts in the same column are significantly different $(P<0.05)$

IEW (g) = Initial egg weight (g), EW ( $\mathrm{g}-6 \mathrm{~d})=$ Egg weight at 6 day, RWL $(\%)=$ Relative water loss, NIT= Normal incubation temperature, $\mathrm{CIT}=$ Chronic incubation temperature, $\mathrm{NC}=$ Negative control, $\mathrm{PC}=\mathrm{Positive}$ control, SEM $=$ Standard error of mean

Table 2 Impact of incubation temperature, betaine manipulations and their interaction on hatchability traits, chick weight at hatch and cloaca temperature 


\begin{tabular}{|c|c|c|c|c|c|c|}
\hline \multirow[t]{2}{*}{ Traits } & \multicolumn{3}{|c|}{ Hatchability traits } & \multirow{2}{*}{$\begin{array}{l}\text { Chick } \\
\text { weight at } \\
\text { hatch } \\
\text { (g) }\end{array}$} & \multirow{2}{*}{$\begin{array}{l}\text { RCW } \\
(\%)\end{array}$} & \multirow{2}{*}{$\begin{array}{l}\text { Cloaca } \\
\text { temperature } \\
\left({ }^{\circ} \mathrm{C}\right)\end{array}$} \\
\hline & $\begin{array}{l}\text { Hatchability } \\
\text { (\%) }\end{array}$ & $\begin{array}{l}\text { Incubation } \\
\text { period (hours) }\end{array}$ & $\begin{array}{l}\text { TEPH } \\
\text { ( hours) }\end{array}$ & & & \\
\hline \multicolumn{7}{|c|}{ Incubation temperature (IT) } \\
\hline $\mathrm{NIT}\left(37.5^{\circ} \mathrm{C}\right)$ & 56.93 & $407.1^{\mathrm{a}}$ & $22.73^{a}$ & $7.72^{\mathrm{a}}$ & 70.05 & $39.61^{b}$ \\
\hline $\mathrm{CIT}\left(39.0^{\circ} \mathrm{C}\right)$ & 53.80 & $384.7^{b}$ & $15.67^{b}$ & $7.51^{\mathrm{b}}$ & 68.03 & $39.97^{a}$ \\
\hline SEM & 2.98 & 6.44 & 1.03 & 0.04 & 0.70 & 0.08 \\
\hline \multicolumn{7}{|c|}{ Betaine manipulations (BM) } \\
\hline $\begin{array}{l}\text { T1 (Negative } \\
\text { control) }\end{array}$ & $46.50^{b}$ & 405.8 & 20.50 & $7.54^{\mathrm{b}}$ & 68.39 & 39.98 \\
\hline $\begin{array}{l}\text { T2 (Positive } \\
\text { control) }\end{array}$ & $51.33^{\mathrm{ab}}$ & 395.8 & 22.00 & $7.43^{b}$ & 67.84 & 39.86 \\
\hline T3 (500mg/L) & $56.33^{\mathrm{ab}}$ & 393.3 & 17.67 & $7.63^{\mathrm{ab}}$ & 68.47 & 39.69 \\
\hline $\begin{array}{l}\text { T4 } \\
\text { (1000mg/L) }\end{array}$ & $60.00^{\mathrm{ab}}$ & 391.7 & 18.83 & $7.83^{a}$ & 70.39 & 39.70 \\
\hline $\begin{array}{l}\text { T5 } \\
\text { (2000mg/L) }\end{array}$ & $62.67^{a}$ & 392.8 & 17.50 & $7.64^{\mathrm{ab}}$ & 70.11 & 39.71 \\
\hline SEM & 4.72 & 10.2 & 1.63 & 0.07 & 1.11 & 0.12 \\
\hline \multicolumn{7}{|l|}{ Probability } \\
\hline IT & 0.467 & 0.023 & 0.0001 & 0.0028 & 0.050 & 0.0020 \\
\hline BM & 0.015 & 0.861 & 0.252 & 0.0058 & 0.401 & 0.3669 \\
\hline IT×BM & 0.992 & 0.983 & 0.781 & 0.3439 & 0.677 & 0.7786 \\
\hline
\end{tabular}

A, b Means with different superscripts in the same row are significantly different $(P<0.05)$

$\mathrm{TEPH}=$ Time between external piping and hatching, RCW (\%) =Relative chick weight (\%), NIT= Normal incubation temperature, $\mathrm{CIT}=$ Chronic incubation temperature, $\mathrm{NC}=$ Negative control, $\mathrm{PC}=\mathrm{Positive}$ control, SEM $=$ Standard error of mean

Table 3 Impact of incubation temperature, betaine manipulations and their interaction on carcass traits of newly-hatching chicks 


\begin{tabular}{|lclllllll|}
\hline Traits & $\begin{array}{l}\text { CWBS } \\
(\mathrm{g})\end{array}$ & $\begin{array}{l}\text { CWAS } \\
(\mathrm{g})\end{array}$ & $\begin{array}{l}\text { RYSW } \\
(\%)\end{array}$ & $\begin{array}{l}\text { Heart } \\
(\%)\end{array}$ & $\begin{array}{l}\text { Intestine } \\
(\%)\end{array}$ & $\begin{array}{l}\text { Gizzard } \\
(\%)\end{array}$ & $\begin{array}{l}\text { Liver } \\
(\%)\end{array}$ & $\begin{array}{l}\text { ECW } \\
(\%)\end{array}$ \\
\hline Incubation temperature (IT) & & & & & & & \\
\hline NIT $\left(37.5^{\circ} \mathrm{C}\right)$ & $7.78^{\mathrm{a}}$ & $7.34^{\mathrm{a}}$ & 5.269 & $1.05^{\mathrm{a}}$ & 4.83 & 5.55 & $2.92^{\mathrm{b}}$ & 68.50 \\
\hline CIT $\left(39.0^{\circ} \mathrm{C}\right)$ & $7.29^{\mathrm{b}}$ & $6.88^{\mathrm{b}}$ & 4.939 & $0.86^{\mathrm{b}}$ & 5.09 & 5.08 & $3.73^{\mathrm{a}}$ & 68.03 \\
\hline SEM & 0.12 & 0.12 & 0.35 & 0.05 & 0.29 & 0.21 & 0.17 & 0.94 \\
\hline Betaine manipulations (BM) & & & & & & & \\
\hline $\begin{array}{l}\text { T1 (Negative } \\
\text { control) }\end{array}$ & $7.55^{\mathrm{ab}}$ & $7.13^{\mathrm{ab}}$ & 4.90 & 0.87 & 4.54 & 5.03 & 3.09 & 68.54 \\
\hline $\begin{array}{l}\text { T2 (Positive } \\
\text { control) }\end{array}$ & $7.47^{\mathrm{ab}}$ & $7.06^{\mathrm{ab}}$ & 5.05 & 0.94 & 4.84 & 5.17 & 3.18 & 68.16 \\
\hline T3 (500mg/L) & $7.12^{\mathrm{b}}$ & $6.69^{\mathrm{b}}$ & 5.16 & 0.98 & 4.83 & 5.26 & 3.33 & 68.60 \\
\hline T4 (1000mg/L) & $7.99^{\mathrm{a}}$ & $7.57^{\mathrm{a}}$ & 5.13 & 0.99 & 5.33 & 5.34 & 3.39 & 67.66 \\
\hline T5 (2000mg/L) & $7.57^{\mathrm{ab}}$ & $7.08^{\mathrm{ab}}$ & 5.27 & 1.01 & 5.27 & 5.77 & 3.62 & 68.36 \\
\hline SEM & 0.19 & 0.19 & 0.54 & 0.08 & 0.46 & 0.34 & 0.27 & 1.48 \\
\hline Probability & & & & & & & & \\
\hline IT & 0.054 & 0.045 & 0.993 & 0.809 & 0.726 & 0.615 & 0.689 & 0.992 \\
\hline BM & 0.226 & 0.999 & 0.958 & 0.976 & 0.992 & 0.971 & 0.999 \\
\hline IT×BM & 0.010 & 0.506 & 0.015 & 0.537 & 0.132 & 0.002 & 0.728 \\
\hline
\end{tabular}

A, b Means with different superscripts in the same row are significantly different $(P<0.05)$.

CWBS $(\mathrm{g})=$ Chick weight before slaughtering, CWAS $(\mathrm{g})=$ Chick weight after slaughtering, RYSW $(\%)=$ Residual yolk sac weight (\%), ECW (\%) = Empty chick weight. NIT= Normal incubation temperature, CIT= Chronic incubation temperature, $\mathrm{NC}=$ Negative control, $\mathrm{PC}=$ Positive control, $\mathrm{SEM}=\mathrm{Standard}$ error of mean Table 4 Impact of incubation temperature, betaine manipulations and their interaction on productive performance of female quails during experimental period (hatch-42day of age) 


\begin{tabular}{|c|c|c|c|c|c|c|c|}
\hline Traits & $\begin{array}{l}\text { One } \\
\text { day }\end{array}$ & $\begin{array}{l}42 \\
\text { days }\end{array}$ & $\begin{array}{l}\text { TWG } \\
\text { (g) }\end{array}$ & $\begin{array}{l}\text { TFC } \\
\text { (g) }\end{array}$ & $\begin{array}{l}\text { FCR (g feed/g } \\
\text { meat) }\end{array}$ & $\begin{array}{l}\text { AFE } \\
\text { (day) }\end{array}$ & $\begin{array}{l}\text { WFE } \\
(\mathrm{g})\end{array}$ \\
\hline \multicolumn{8}{|c|}{ Effect of incubation temperature (IT) } \\
\hline NIT $\left(37.5^{\circ} \mathrm{C}\right)$ & 7.74 & $217.5^{\mathrm{a}}$ & 209.7 & 637.1 & 3.06 & 41.33 & $8.60^{\mathrm{a}}$ \\
\hline $\mathrm{CIT}\left(39.0^{\circ} \mathrm{C}\right)$ & 7.37 & $212.2^{b}$ & 204.9 & 606.2 & 2.97 & 40.73 & $7.59^{b}$ \\
\hline SEM & 0.2 & 1.7 & 1.8 & 11.4 & 0.06 & 0.05 & 0.20 \\
\hline \multicolumn{8}{|c|}{ Betaine manipulations (BM) } \\
\hline $\begin{array}{l}\text { T1(Negative } \\
\text { control) }\end{array}$ & 7.57 & $207.3^{b}$ & $199.7^{b}$ & $790.7^{a}$ & $3.97^{\mathrm{a}}$ & $41.00^{\mathrm{ab}}$ & $7.48^{\mathrm{b}}$ \\
\hline $\begin{array}{l}\text { T2(Positive } \\
\text { control) }\end{array}$ & 7.37 & $214.6^{\mathrm{ab}}$ & $207.2^{\mathrm{ab}}$ & $645.6^{b}$ & $3.12^{\mathrm{b}}$ & $41.17^{\mathrm{ab}}$ & $8.23^{\mathrm{ab}}$ \\
\hline T3 (500mg/L) & 6.97 & $215.2^{\mathrm{ab}}$ & $208.2^{\mathrm{ab}}$ & $588.7^{\mathrm{C}}$ & $2.83^{b c}$ & $41.17^{\mathrm{ab}}$ & $8.00^{\mathrm{ab}}$ \\
\hline T4 (1000mg/L) & 8.26 & $220.6^{a}$ & $212.4^{\mathrm{a}}$ & $527.2^{\mathrm{cd}}$ & $2.48^{\mathrm{cd}}$ & $42.33^{a}$ & $8.08^{\mathrm{ab}}$ \\
\hline T5 (2000mg/L) & 7.61 & $216.5^{\mathrm{a}}$ & $208.9^{a}$ & $555.9^{d}$ & $2.67^{d}$ & $39.50^{b}$ & $8.62^{\mathrm{a}}$ \\
\hline SEM & 0.3 & 2.8 & 8.2 & 18.1 & 0.12 & 0.77 & 0.32 \\
\hline \multicolumn{8}{|l|}{ Probability } \\
\hline IT & 0.202 & 0.047 & 0.065 & 0.071 & 0.373 & 0.395 & 0.002 \\
\hline AA & 0.113 & 0.043 & 0.054 & 0.0001 & 0.0001 & 0.019 & 0.015 \\
\hline IT×BM & 0.398 & 0.215 & 0.200 & 0.0001 & 0.0001 & 0.671 & 0.229 \\
\hline
\end{tabular}

$A, b, c$ Means with different superscripts in the same row are significantly different $(P<0.05)$.

TWG $(\mathrm{g})=$ Total weight gain $(\mathrm{g})$, TFC $(\mathrm{g})=$ Total feed consumption, FCR $(\mathrm{g}$ feed $/ \mathrm{g}$ meat) = Feed conversion ratio, AFE (day) = Age at laying first egg, WFE $(\mathrm{g})=$ Weight first egg $(\mathrm{g})$, NIT= Normal incubation temperature, $\mathrm{CIT}=$ Chronic incubation temperature.

Table 5 Impact of incubation temperature, betaine manipulations and their interaction on female carcass traits of female quails 


\begin{tabular}{|c|c|c|c|c|c|c|c|c|c|}
\hline \multirow[t]{3}{*}{ Traits } & \multirow{3}{*}{$\begin{array}{l}\text { LBW } \\
\text { (g) }\end{array}$} & \multirow{3}{*}{$\begin{array}{l}\text { EC } \\
(\%)\end{array}$} & \multicolumn{3}{|c|}{ Heart parameters } & \multirow{3}{*}{$\begin{array}{l}\text { Intestine } \\
(\%)\end{array}$} & \multirow{3}{*}{$\begin{array}{l}\text { Liver } \\
(\%)\end{array}$} & \multirow{3}{*}{$\begin{array}{l}\text { Gizzard } \\
(\%)\end{array}$} & \multirow{3}{*}{$\begin{array}{l}\text { Spleen } \\
(\%)\end{array}$} \\
\hline & & & RV & TV & $\mathrm{RV} / \mathrm{TV}$ & & & & \\
\hline & & & (g) & (g) & & & & & \\
\hline \multicolumn{10}{|c|}{ Incubation temperature (IT) } \\
\hline $\begin{array}{l}\text { NIT } \\
\left(37.5^{\circ} \mathrm{C}\right)\end{array}$ & 247.0 & 65.15 & $0.418^{b}$ & $2.104^{a}$ & $0.205^{b}$ & 6.40 & 2.64 & 1.70 & $0.065^{\mathrm{a}}$ \\
\hline $\begin{array}{l}\text { CIT } \\
\left(39.0^{\circ} \mathrm{C}\right)\end{array}$ & 234.8 & 64.25 & $0.493^{\mathrm{a}}$ & $1.659^{b}$ & $0.308^{a}$ & 5.93 & 2.37 & 1.58 & $0.049^{b}$ \\
\hline SEM & 6.15 & 0.86 & 0.012 & 0.09 & 0.01 & 0.20 & 0.16 & 0.09 & 0.004 \\
\hline \multicolumn{10}{|c|}{ Betaine manipulations (BM) } \\
\hline $\mathrm{T} 1$ (NC) & 233.5 & 66.39 & 0.488 & 1.622 & $0.325^{a}$ & 6.36 & 2.34 & 1.79 & 0.062 \\
\hline T2 (PC) & 250.0 & 64.16 & 0.474 & 1.933 & $0.249^{b}$ & 6.26 & 2.25 & 1.54 & 0.049 \\
\hline $\begin{array}{l}\text { T3 } \\
\text { (500mg/L) }\end{array}$ & 252.5 & 64.60 & 0.468 & 1.882 & $0.256^{\mathrm{b}}$ & 6.11 & 2.64 & 1.64 & 0.056 \\
\hline $\begin{array}{l}\text { T4 } \\
(1000 \mathrm{mg} / \mathrm{L})\end{array}$ & 241.9 & 64.65 & 0.417 & 2.050 & $0.220^{b}$ & 6.35 & 2.50 & 1.74 & 0.047 \\
\hline $\begin{array}{l}\text { T5 } \\
(2000 \mathrm{mg} / \mathrm{L})\end{array}$ & 226.5 & 63.71 & 0.430 & 1.922 & $0.232^{b}$ & 5.75 & 2.81 & 1.50 & 0.072 \\
\hline SEM & 9.66 & 1.35 & 0.02 & 0.14 & 0.014 & 0.31 & 0.25 & 0.14 & 0.01 \\
\hline \multicolumn{10}{|l|}{ Probability } \\
\hline IT & 0.177 & 0.465 & 0.001 & 0.003 & 0.0001 & 0.116 & 0.252 & 0.322 & 0.022 \\
\hline BM & 0.312 & 0.689 & 0.110 & 0.359 & 0.001 & 0.630 & 0.511 & 0.554 & 0.142 \\
\hline IT×BM & 0.420 & $\begin{array}{l}0 . \\
308\end{array}$ & 0.180 & 0.340 & 0.002 & 0.290 & 0.562 & 0.599 & 0.305 \\
\hline
\end{tabular}

$A, b, c$ Means with different superscripts in the same row are significantly different $(P<0.05)$.

LBW (g) = Life body weight, EC (\%) = Eviscerated carcass (\%), RV= Right Ventricle, TV= Total Ventricle and RV: TV ratio, NIT = Normal incubation temperature, $\mathrm{CIT}=$ Chronic incubation temperature, $\mathrm{NC}=$ Negative control, PC= Positive control, SEM= Standard error of mean

Table 6 Impact of incubation temperature, betaine manipulations and their interaction on female reproductive traits of female quails 


\begin{tabular}{|c|c|c|c|c|c|c|c|c|}
\hline \multirow[t]{2}{*}{ Traits } & \multicolumn{2}{|l|}{ Ovary } & \multirow[t]{2}{*}{ Oviduct (\%) } & \multicolumn{5}{|c|}{ Largest follicle weights } \\
\hline & (g) & $(\%)$ & & F1 & F2 & F3 & F4 & F5 \\
\hline \multicolumn{9}{|c|}{ Incubation temperature (IT) } \\
\hline $\mathrm{NIT}\left(37.5^{\circ} \mathrm{C}\right)$ & 8.10 & 3.26 & 3.30 & 2.103 & 1.737 & 1.520 & 1.256 & 0.783 \\
\hline $\operatorname{CIT}\left(39.0^{\circ} \mathrm{C}\right)$ & 6.85 & 2.95 & 3.11 & 2.128 & 1.761 & 1.438 & 0.903 & 0.482 \\
\hline SEM & 0.78 & 0.29 & 0.07 & 0.17 & 0.19 & 0.21 & 0.19 & 0.17 \\
\hline \multicolumn{9}{|c|}{ Betaine manipulations (BM) } \\
\hline T1 (Negative control) & 6.23 & 2.62 & $3.09^{b c}$ & 2.245 & 1.650 & 1.587 & 1.195 & 0.520 \\
\hline T2 (Positive control) & 8.02 & 3.21 & $3.04^{c}$ & 1.997 & 1.772 & 1.343 & 0.812 & 0.645 \\
\hline T3 (500mg/L) & 6.75 & 2.72 & $2.97^{\mathrm{C}}$ & 1.740 & 1.537 & 1.460 & 1.003 & 0.507 \\
\hline T4 (1000mg/L) & 7.06 & 2.95 & $3.42^{\mathrm{ab}}$ & 2.252 & 1.495 & 1.367 & 0.787 & 0.617 \\
\hline T5 (2000mg/L) & 9.33 & 4.02 & $3.51^{\mathrm{a}}$ & 2.347 & 2.292 & 1.639 & 1.602 & 0.875 \\
\hline SEM & 1.22 & 0.46 & 0.12 & 0.26 & 0.29 & 0.34 & 0.30 & 0.27 \\
\hline \multicolumn{9}{|l|}{ Probability } \\
\hline IT & 0.269 & 0.453 & 0.080 & 0.927 & 0.935 & 0.774 & 0.205 & 0.232 \\
\hline BM & 0.432 & 0.242 & 0.013 & 0.503 & 0.345 & 0.956 & 0.323 & 0.876 \\
\hline IT×BM & 0.145 & 0.076 & 0.222 & 0.462 & 0.368 & 0.244 & 0.384 & 0.910 \\
\hline
\end{tabular}

$A, b, c$ Means with different superscripts in the same row are significantly different $(P<0.05)$.

$\mathrm{NIT}=$ Normal incubation temperature, $\mathrm{CIT}=$ Chronic incubation temperature, $\mathrm{SEM}=$ Standard error of mean

Table 7 Impact of incubation temperature, betaine manipulations and their interaction on hematological parameters and blood proteins of female quails 


\begin{tabular}{|c|c|c|c|c|c|c|c|}
\hline \multirow[t]{2}{*}{ Traits } & \multirow{2}{*}{$\begin{array}{l}\text { RBC } \\
\left(\times 10^{6}\right)\end{array}$} & \multirow{2}{*}{$\begin{array}{l}\text { WBC } \\
\left(\times 10^{3} / \mathrm{ul}\right)\end{array}$} & \multirow{2}{*}{$\begin{array}{l}\mathrm{Hb} \\
(\mathrm{g} / \mathrm{dl})\end{array}$} & \multirow{2}{*}{$\begin{array}{l}\mathrm{H} / \mathrm{L} \\
\text { ratio }\end{array}$} & \multicolumn{3}{|c|}{ Blood proteins } \\
\hline & & & & & $\begin{array}{l}\text { Total protein } \\
(\mathrm{mg} / \mathrm{dl})\end{array}$ & $\begin{array}{l}\text { Albumin } \\
\text { (mg/dl) }\end{array}$ & $\begin{array}{l}\text { Globulin } \\
\text { (mg/dl) }\end{array}$ \\
\hline \multicolumn{8}{|c|}{ Effect of incubation temperature (IT) } \\
\hline $\operatorname{NIT}\left(37.5^{\circ} \mathrm{C}\right)$ & $2.986^{b}$ & $106.80^{a}$ & 11.94 & $0.487^{b}$ & $5.91^{\mathrm{a}}$ & $4.07^{\mathrm{a}}$ & $1.84^{\mathrm{a}}$ \\
\hline $\operatorname{CIT}\left(39.0^{\circ} \mathrm{C}\right)$ & $3.194^{\mathrm{a}}$ & $92.80^{\mathrm{b}}$ & 10.82 & $0.573^{a}$ & $4.82^{\mathrm{b}}$ & $3.17^{b}$ & $1.65^{\mathrm{b}}$ \\
\hline SEM & 0.05 & 2.52 & 0.45 & 0.01 & 0.08 & 0.08 & 0.02 \\
\hline \multicolumn{8}{|c|}{ Betaine manipulations (BM) } \\
\hline $\begin{array}{l}\text { T1 (Negative } \\
\text { control) }\end{array}$ & 3.082 & $81.75^{\mathrm{b}}$ & 10.58 & 0.531 & $4.54^{\mathrm{d}}$ & $3.08^{\mathrm{c}}$ & $1.46^{\mathrm{d}}$ \\
\hline $\begin{array}{l}\text { T2 (Positive } \\
\text { control) }\end{array}$ & 3.068 & $90.77^{b}$ & 10.73 & 0.517 & $5.13^{c}$ & $3.42^{\mathrm{bc}}$ & $1.71^{\mathrm{c}}$ \\
\hline T3 (500mg/L) & 3.118 & $103.87^{a}$ & 11.56 & 0.530 & $5.44^{\mathrm{bc}}$ & $3.74^{\mathrm{ab}}$ & $1.70^{\mathrm{C}}$ \\
\hline $\mathrm{T} 4(1000 \mathrm{mg} / \mathrm{L})$ & 3.130 & $108.20^{a}$ & 11.93 & 0.535 & $5.64^{b}$ & $3.79^{a b}$ & $1.85^{\mathrm{b}}$ \\
\hline T5(2000mg/L) & 3.052 & $114.40^{\mathrm{a}}$ & 12.08 & 0.537 & $6.05^{\mathrm{a}}$ & $4.06^{\mathrm{a}}$ & $1.99^{a}$ \\
\hline SEM & 0.08 & 3.99 & 0.72 & 0.018 & 0.12 & 0.12 & 0.03 \\
\hline \multicolumn{8}{|l|}{ Probability } \\
\hline IT & 0.011 & 0.001 & 0.097 & 0.0001 & 0.0001 & 0.0001 & 0.0001 \\
\hline BM & 0.956 & 0.0001 & 0.482 & 0.940 & 0.0001 & 0.0002 & 0.0001 \\
\hline IT×BM & 0.920 & 1.000 & 0.999 & 0.482 & 0.074 & 0.121 & 0.226 \\
\hline
\end{tabular}

$A, b, c$ Means with different superscripts in the same row are significantly different $(P<0.05)$.

$\mathrm{NIT}=$ Normal incubation temperature, $\mathrm{CIT}=$ Chronic incubation temperature, $\mathrm{NC}=$ Negative control, $\mathrm{PC}=$ Positive control, RBC $(\times 106)=$ Red blood cells, WBC $(\times 103 / \mathrm{ul})=$ White blood cells, SEM= Standard error of mean

Table 8. Impact of incubation temperature, betaine manipulations and their interaction on liver enzymes, triglyceride, cholesterol and T3 hormone of female quails 


\begin{tabular}{|c|c|c|c|c|c|}
\hline \multirow[t]{3}{*}{ Traits } & \multicolumn{2}{|c|}{ Liver enzymes } & \multirow{3}{*}{$\begin{array}{l}\text { Triglyceride } \\
(\mathrm{mg} / \mathrm{dl})\end{array}$} & \multirow{3}{*}{$\begin{array}{l}\text { Cholesterol } \\
(\mathrm{mg} / \mathrm{dl})\end{array}$} & \multirow{3}{*}{$\begin{array}{l}\text { T3 } \\
(\mu g \mathrm{~L}-1)\end{array}$} \\
\hline & ALT & AST & & & \\
\hline & $(\mathrm{U} / \mathrm{I})$ & $(\mathrm{U} / \mathrm{I})$ & & & \\
\hline \multicolumn{6}{|c|}{ Effect of incubation temperature } \\
\hline $\operatorname{NIT}\left(37.5^{\circ} \mathrm{C}\right)$ & $9.96^{b}$ & $11.64^{\mathrm{b}}$ & $176.87^{b}$ & $172.80^{b}$ & $84.88^{a}$ \\
\hline $\mathrm{CIT}\left(39.0^{\circ} \mathrm{C}\right)$ & $12.17^{\mathrm{a}}$ & $16.30^{\mathrm{a}}$ & $203.33^{a}$ & $188.67^{a}$ & $72.76^{b}$ \\
\hline SEM & 0.576 & 0.188 & 1.990 & 3.101 & 1.268 \\
\hline \multicolumn{6}{|c|}{ Betaine manipulations (BM) } \\
\hline T1 (Negative control) & $12.97^{\mathrm{a}}$ & $14.62^{\mathrm{a}}$ & $196.50^{a}$ & $194.66^{\mathrm{a}}$ & $74.69^{b}$ \\
\hline T2 (Positive control) & $12.59^{\mathrm{ab}}$ & $14.27^{\mathrm{ab}}$ & $194.50^{\mathrm{a}}$ & $195.66^{a}$ & $76.91^{\mathrm{ab}}$ \\
\hline T3 (500mg/L) & $10.96^{\mathrm{bc}}$ & $14.02^{\mathrm{ab}}$ & $188.83^{\mathrm{ab}}$ & $175.33^{b}$ & $78.6^{\mathrm{ab}}$ \\
\hline T4 (1000mg/L) & $9.90^{\mathrm{bc}}$ & $13.47^{b}$ & $183.50^{\mathrm{ab}}$ & $169.67^{\mathrm{b}}$ & $81.33^{a}$ \\
\hline T5 (2000mg/L) & $8.92^{\mathrm{c}}$ & $13.46^{\mathrm{b}}$ & $187.17^{b}$ & $168.33^{b}$ & $82.53^{a}$ \\
\hline SEM & 0.912 & 0.298 & 3.147 & 4.903 & 2.004 \\
\hline \multicolumn{6}{|l|}{ Probability } \\
\hline IT & 0.014 & 0.0001 & 0.0001 & 0.002 & 0.0001 \\
\hline BM & 0.023 & 0.051 & 0.049 & 0.001 & 0.027 \\
\hline $\mathrm{IT} \times \mathrm{BM}$ & 0.999 & 0.992 & 0.948 & 0.998 & 0.996 \\
\hline
\end{tabular}

$A, b, c$ Means with different superscripts in the same row are significantly different $(P<0.05)$.

$\mathrm{NIT}=$ Normal incubation temperature, $\mathrm{CIT}=$ Chronic incubation temperature, $\mathrm{SEM}=$ Standard error of mean 